\title{
Physicochemical and microbial assessment of some creeklets associated with urban runoff in yenagoa metropolis
}

\begin{abstract}
Urban runoff have become a major source of surface and ground water pollution in most developing nations, where municipal waste streams are uncharacterized or segregated. Bayelsa state, is a wetland located in the Southernmost and Central part of Niger Delta, in Nigeria. This study evaluated the physicochemical and Microbial quality of recipient creeklets of urban runoff in Yenagoa Metropolis, being the Capital city of Bayelsa state. Water samples were collected from 6 randomly selected creeklets, and analyzed following standard protocol. Results of physicochemical parameters were reported as; temperature $\left(27.96 \pm 0.30-29.01 \pm 0.27^{\circ} \mathrm{C}\right), \mathrm{pH}(6.60 \pm 0.52$ $6.81 \pm 0.56)$, Dissolved oxygen $(3.80 \pm 0.48-8.90 \pm 0.27 \mathrm{mg} / 1)$, Turbidity $(17.94 \pm 0.05$ $31.97 \pm 0.83 \mathrm{NTU})$, conductivity $(67.67 \pm 0.13-55.31 \pm 0.42 \mu \mathrm{S} / \mathrm{cm})$, and Total dissolved solid (TDS), ranging from $51.20 \pm 0.66-111.50 \pm 0.29 \mathrm{mg} / 1(\mathrm{P}<0.05)$. While the levels of nitrite range from $1.45 \pm 0.03-3.94 \pm 0.53 \mathrm{mg} / \mathrm{l}$, Total heterotrophic bacteria and fungi were $0.65 \pm 0.11-1.35 \pm 0.71 \times 10^{6}$ and $0.46 \pm 0.33-0.77 \pm 0.62 \times 10^{4} \mathrm{Cfu} / \mathrm{ml}$ respectively. Furthermore, the total and feacal coliforms were 161.18 $\pm 9.30-256.14 \pm 4.90$ and $81.15 \pm 9.90-169.11 \pm 3.71 \mathrm{MPN} / 100 \mathrm{ml}$ respectively. The results generally indicated significant levels of contamination of the creeklet due to anthropogenic activities. As such, Government, NGOs and all stakeholders should formulate mitigable measures to check anthropogenic activities.
\end{abstract}

Keywords: niger delta, Creeklet, microorganisms, physicochemistry, urban runoff
Volume 4 Issue 4 - 2018

\section{Enetimi I Seiyaboh, Tariwari CN Angaye}

Department of Biological Science, Faculty of Science, Niger Delta University, Nigeria

Correspondence: Tariwari CN Angaye, Department of Biological Science, Faculty of Science, Niger Delta University, Wilberforce Island, Bayelsa State, Nigeria, Email maktarry@yahoo.com

Received: July 30, 2018 | Published: August 23, 2018

\section{Introduction}

Water is an essential resource to biodiversity largely because all organism depend on water for survival and sustenance. As documented in literature, the quality of river water plays a vital role to the relative public health and sustenance of any given community or ecosystem. For instance, anthropogenic activities have the tendency to release toxic organic and inorganic leachates from waste stream which are transported by urban runoff to contaminate water bodies. ${ }^{2,3}$ Persistent inflow of waste stream from urban runoffs have largely affected the ambient water quality of aligning water bodies. It has been observed that in some communities of most developing countries surface water still serve as a means for waste disposal, especially in riverine communities. ${ }^{3}$ Persistent anthropogenic activities over a period of time may influence the contamination rate.

The contamination of water bodies from leachates of urban runoff due to unregulated and illicit dumping of unsegregated and untreated treated waste stream have been reported by several authors. ${ }^{1-6}$ Some of the envisaged adverse of such contaminated runoff water on such water bodies includes but not limited to; nutrient enrichment, deterioration of the water qualities, and destruction of spawning grounds for aquatic and marine life, general fish kill. ${ }^{2}$ Furthermore, the quality of any water body is largely dependent on its intended purpose. Even the spread of water-borne diseases like typhoid, cholera, diarrhoea from contaminated water have been documented in literature by several. ${ }^{1,7-9}$ Consequent upon the environmental hazards associated with organic and inorganic leachates of waste streams associated with urban runoff and its toxicity to the ecosystem; it has become necessary to investigate the potential hazards associated with urban runoffs.

\section{Materials and methods}

\section{Study area}

Yenagoa metropolis is the capital city of Bayelsa state of Nigeria, which is located on the southernmost part of Nigeria. It is a wetland consist of several network of creeklets which is linked to a major parent creek called Epie creek. The study area is a tropical humid hot climate with two prevailing seasons, being wet and dry seasons. The wet season which ranges from April to October is relatively cool and rainy, while dry season which is relatively hot and dusty ranges from November to March.

\section{Sampling}

The sampling points are randomly selected dumpsites within the metropolis and the central dumpsite located on the outskirt of the metropolis. A total of 6 creeklet water samples (control inclusive), were collected in triplicates from 5 creeklets (Amarata, Okutukutu, Etegwe, Akenpai, Agudama), and one control station outside the metropolis. Samples for physicochemistry were monitored insitu, while samples for microbiological analysis were packaged in sterile Mc-cathney bottles and transported to the laboratory in ice pack.

\section{Techniques for physicochemical analysis}

Physicochemical parameters like; $\mathrm{pH}$ and Total dissolved Solid (TDS) were measured insitu using portable digital multi-probe meter (EXTECH-DO700). In the same vein, Salinity and conductivity were measured insitu using EXTECH-EC400 multi-probe meter, while turbidity and Total Suspended Solid (TSS) were assessed with the EXTECH-TB400 Turbidity meter and Envco-1500 TSS Meter respectively. 


\section{Techniques for microbial analysis}

The microbial inoculation and density enumeration of the soil samples was carried out using serial dilution and pour plate technique as described by several authors. ${ }^{10,11}$ About $1.0 \mathrm{ml}$ aliquots of the water samples was dispense into the $9.0 \mathrm{ml}$ of sterile distilled water in plugged test tube and agitated for even distribution, making a dilution factor ranging from $10^{-1}$ to $10^{-7}$ was achieved from the first diluent. About $1 \mathrm{ml}$ of each diluent from the respective test tubes were aseptically pipetted unto the individual labelled sterilized Petri dishes. The inoculation was carried out in a laminar flow, the inoculated plates were inverted prior to their transfer to the incubator. The media used for the study were Nutrient Agar for Total Heterotrophic Bacteria (THB) at $35^{\circ} \mathrm{C}$ for 24-48hours, Sabouraud dextrose agar for Total Fungi (TF) $28 \pm 2^{\circ} \mathrm{C}$ for 72-96hours. Furthermore, MacConkey broth for was used for the culture of Total and Feacal Coliforms $37^{\circ} \mathrm{C}$ for $24-48$ hours. ${ }^{12}$

\section{Statistical analysis}

All statistical analysis for the purpose of this research were carried out using SPSS software (SPSS Inc, Chicago; version 20). One-way analysis of variance was used for mean separation at $\mathrm{P}=0.05$, While Duncan's multiple range test (DMR) was used for the source of differences.

\section{Results and discussions}

Table 1 presents the physicochemical properties of the creeklets in Yenagoa Metropolis of Bayelsa state Nigeria. Result showed that temperature of the creeklet water sample ranged from $27.96 \pm 0.30$ $29.01 \pm 0.27^{\circ} \mathrm{C}$. The temperature recorded in this study were within ambient range. As established in literature optimal temperature is required for the sustainability of biodiversity, as extreme temperature might oblige the proliferation of exotic/alien species. ${ }^{1}$ The temperature values of this study is comparable to values reported by other authors, in the study area for Epie creek $27.3-29.3^{\circ} \mathrm{C},{ }^{2}$ and $28.36-30.10^{\circ} \mathrm{C}$ for Efi lake. ${ }^{1}$ The $\mathrm{pH}$ values of this study ranged from $6.60 \pm 0.52$ - 6.81 \pm 0.56 , which was within the stipulated limits of the WHO (6.50-8.50). Notwithstanding, the $\mathrm{pH}$ of this study is comparable to values reported by other authors, in the study area for Efi lake 6.55 $-7.20,{ }^{17} 7.4-7.57$ in dry season and 6.9-7.33 in wet season for Epie creek, ${ }^{2} 6.95-7.50$ for lower Kolo creek, ${ }^{13} 7.17$ for upper river Nun, ${ }^{14}$ 6.8-8.5 for Nkoro River ${ }^{15}$ as well as values ranging from 6.5-7.11 for Igedi river and 6.5-6.73 for River Nun. ${ }^{3}$ Acidic or alkalinic $\mathrm{pH}$ indicates elemental contamination of water bodies, which have the propensity to adversely affect biodiversity. The result of this study indicates optimal $\mathrm{pH}$.

The spatial levels dissolved oxygen (DO) amongst the creeklet ranged from $3.80 \pm 0.48-8.90 \pm 0.27 \mathrm{mg} / \mathrm{l}$, with significant difference $(\mathrm{P}<0.05)$ amongst the sampling stations (Table 1). Although, there is no specified level for DO. But ambient or tolerant DO level varies for depending on the affected organism. For instance, low level of DO may be toxic to some aquatic organism, ${ }^{17}$ especially if lower than $2.0 \mathrm{mg} / 1 .{ }^{16}$ Also DO solubility can be affected by high temperature as such there is an inverse correlation between temperature and DO. $^{2}$ Comparatively, ${ }^{3}$ reported DO levels of $10.200 \pm 0.283$ and $14.225 \pm 0.263 \mathrm{mg} / \mathrm{l}$ for Igbedi and Ogobiri around the river Nun which was higher than values of this study. However, the DO level reported by Seiyaboh et al. ${ }^{18}$ ranging from $4.8 \mathrm{mg} / 1-7.2 \mathrm{mg} / 1$ was in tandem with values of our study. Efi Lake had DO levels in the range of 9.07$19.52 \mathrm{mg} / 1 .{ }^{1}$ DO levels of $5.0-7.92 \mathrm{mg} / 1$ was reported for Kolo creek, ${ }^{13}$ $1.38-9.06$ and $1.76-5.68 \mathrm{mg} / 1$ for dry and wet seasons of Epie creek respectively. ${ }^{2}$

The turbidity levels of the water sample from the creeklet ranged from $17.94 \pm 0.05-31.97 \pm 0.83 \mathrm{NTU}$, with the most and least turbid values in Agudama and Etegwe stations respectively (Table 1). Notwithstanding, the control station indicated a lower turbidity values compared to stations in the study area $((P<0.05)$. The turbidity values recorded in this study is comparable to values reported by other authors in; upstream and downstream of Nun river of Agudama Ikpetiama with values of $103.752 \pm 2.062$ and $117.002 \pm 2.160 \mathrm{NTU}$ respectively. ${ }^{18}$ Other authors who studied surface water in the Niger delta reported turbidity values 62.54 NTU in Igbedi creek, ${ }^{3} 5-64$ NTU around Tombia bride Agudama Ikpetiama, ${ }^{21} 7.87-17.29 \mathrm{NTU}$ in Efi lake, ${ }^{1}$ Epie creek in dry (11.67-19.67) and wet (16.67-28.00 NTU) seasons, ${ }^{2}$ and Kolo creek with values of $35.0-40.5$ NTU. ${ }^{13}$ While the control station indicated the lowest value, the conductivity of the creeklets ranged from $67.67 \pm 0.13-55.31 \pm 0.42 \mu \mathrm{S} / \mathrm{cm}$ (Table 1); with Agudama and Etegew Stations having the highest and lowest values respectively $(\mathrm{P}<0.05)$. Our values is comparable to $48.13-68.93 \mu \mathrm{S} /$ $\mathrm{cm}$ obtained for Efi Lake. ${ }^{1}$ As documented values of Amassoma and Agudama-Ekpetima were $56.075 \pm 0.591$ and $64.950 \pm 0.681 \mu \mathrm{S} / \mathrm{cm}$. Other conductivity values were reprted for Kolo creek 82.30-102.0 $\mu \mathrm{S} /$ $\mathrm{cm}$ for, ${ }^{13}$ Igbedi creek $76.23 \mathrm{umhos} / \mathrm{cm},{ }^{14}$ Tombia bridge construction area $87-95$ umhos $/ \mathrm{cm},{ }^{18}$ as well as values of $18.9-156.4 \mu \mathrm{S} / \mathrm{cm}$ reported by Puyate and Rim-Rukeh.

The level of total dissolved solid (TDS) reported in this study ranged from 51.20 $\pm 0.66-111.50 \pm 0.29 \mathrm{mg} / \mathrm{l}$, with Etegwe and Akenpai stations having the highest and lowest values respectively $(P<0.05)$. In addition, the control station indicated the lowest level of TDS. Our values are comparable to values reported by other authors. In Efi lake values ranged from $54.25-102.92 \mathrm{mg} / 1 .{ }^{1}$ Other authors reported TDS values for Kolo Creek 41.5-51.0 mg/l, ${ }^{13}$ Amassoma and Igbedi axis $28.180 \pm 0.048$ and $32.550 \pm 0.666 \mathrm{mg} / 1$ respectively, ${ }^{1}$ Epie creek $55-62$ for dry season and $33-37.33 \mathrm{mg} / \mathrm{l}$ in wet seasons respectively, as well as values of $62.1-67.9 \mathrm{mg} / 1$ in Tombia axis of the river Nun. Table 2 presents the level of microbes associated with the creeklet including; Total Heterotrophic Bacteria (THB), Total Fungi (TF), Total Coliform (TC) as well as the levels of Feacal Coliform (FC). The levels of enumerated THB and TF ranged from $0.65 \pm 0.11-1.35 \pm 0.71 \mathrm{X} 10^{6}$ and $0.46 \pm 0.33-0.77 \pm 0.62 \quad \mathrm{X} 10^{4} \quad \mathrm{cfu} / \mathrm{ml}$ respectively $(P<0.05)$. Furthermore, the coliform levels were 161.18 $\pm 9.30-256.14 \pm 4.90$ and $81.15 \pm 9.90-169.11 \pm 3.71 \mathrm{MPN} / 100 \mathrm{ml}$ for TC and FC respectively $(P<0.05)$. The qualitative assessment of water is largely dependent on its intended use. For instance, the levels of microbes in portable water must be zero, as recommended by WHO. Notwithstanding, our values reported is comparable to values of Ef lake ranging from 76.72-260.23MPN/100ml for TC, and 53.67-157.02MPN/100 ml FC. ${ }^{1}$ The values of THB were $6.434 \pm 0.039$ and $6.387 \pm 0.055 \mathrm{Log} \mathrm{cfu} / \mathrm{ml}$ for lower and upper Nun Respectively, and $6.414 \pm 0.078 \mathrm{Log} \mathrm{cfu} / \mathrm{ml}$ $6.394 \pm 0.070 \mathrm{Log} \mathrm{cfu} / \mathrm{ml}$ for Ogobiri and Akaibiri respectively. ${ }^{3}$ The levels of microbes detected in the creeklet water indicated significant level of microbial contamination, which can be source of reservoir for the transmission of water borne diseases. In addition exceeding level of microbial density can harm aquatic life, especially fish kill that has been documented in literature. ${ }^{16,19-21}$ 
Table I Results of the physicochemical properties of the creeklets

\begin{tabular}{|c|c|c|c|c|c|c|}
\hline $\begin{array}{l}\text { Sample } \\
\text { Code }\end{array}$ & $\begin{array}{l}\text { Temp. } \\
\left({ }^{\circ} \mathrm{C}\right)\end{array}$ & $\mathrm{pH}$ & $\begin{array}{l}\text { DO } \\
(\mathrm{mg} / \mathrm{l})\end{array}$ & $\begin{array}{l}\text { Turbidity } \\
\text { (NTU) }\end{array}$ & $\begin{array}{l}E C \\
(\mu S / c m)\end{array}$ & $\begin{array}{l}\text { TDS } \\
\text { (mg/l) }\end{array}$ \\
\hline Amarata & $28.14 \pm 0.2 \mathrm{Ib}$ & $6.63 \pm 0.10 \mathrm{~b}$ & $8.90 \pm 0.27 d$ & $24.15 \pm 0.32 \mathrm{e}$ & $61.91 \pm 0.4 \mathrm{le}$ & $90.42 \pm 0.3 \mathrm{Id}$ \\
\hline Okutukutu & $27.96 \pm 0.30 \mathrm{ab}$ & $6.8 \mathrm{I} \pm 0.56 \mathrm{~b}$ & $5.0 \mathrm{I} \pm 0.13 \mathrm{~b}$ & $27.04 \pm 0.69 d$ & $64.5 \mathrm{I} \pm 0.7 \mathrm{If}$ & $111.50 \pm 0.29 e$ \\
\hline Etegwe & $28.1 I \pm 0.38 a$ & $6.6 I \pm 0.7 \mathrm{Ia}$ & $7.48 \pm 0.12 \mathrm{e}$ & $17.94 \pm 0.05 b$ & $66.30 \pm 0.3 \mathrm{Id}$ & $3 \mid 4.34 \pm 2.08 b$ \\
\hline Akenpai & $29.0 I \pm 0.27 b$ & $6.8 \mathrm{I} \pm 0.09 \mathrm{ab}$ & $7.40 \pm 0.42 f$ & $28.91 \pm 0.56 \mathrm{ab}$ & $67.67 \pm 0.13 c$ & $51.20 \pm 0.66 a$ \\
\hline Agudama & $26.98 \pm 0.62 a$ & $6.60 \pm 0.52 d$ & $3.80 \pm 0.48 a$ & $31.97 \pm 0.83 c$ & $55.3 \mathrm{I} \pm 0.42 b$ & $89.98 \pm 0.67 b$ \\
\hline Control & $27.56 \pm 0.3 \mathrm{Ib}$ & $6.89 \pm 0.1 \mathrm{Ic}$ & $11.09 \pm 0.10 c$ & 4. $10 \pm 0.08 a$ & $47.22 \pm 0.03 a$ & $44.42 \pm 0.3 \mathrm{Ic}$ \\
\hline WHO & Ambient & $6.5-8.5$ & - & 5 & 1000 & 500 \\
\hline
\end{tabular}

Table 2 Results of microbiological quality assessment of the creeklets

\begin{tabular}{|c|c|c|c|c|c|}
\hline $\begin{array}{l}\text { Sample } \\
\text { Code }\end{array}$ & $\begin{array}{l}\text { THB, } \times 10^{6} \\
(\mathrm{Cfu} / \mathrm{ml})\end{array}$ & $\begin{array}{l}\text { TF, X } 10^{4} \\
(\mathrm{Cfu} / \mathrm{ml})\end{array}$ & $\begin{array}{l}\text { TC } \\
(\mathrm{MPN} / \mathrm{l} 00 \mathrm{ml})\end{array}$ & $\begin{array}{l}\text { FC } \\
(M P N / 100 \mathrm{ml})\end{array}$ & $\begin{array}{l}\text { Nitrate } \\
(\mathrm{mg} / \mathrm{l})\end{array}$ \\
\hline Amarata & I. $35 \pm 0.7 \mathrm{Ic}$ & $0.92 \pm 0.45 c$ & $256.14 \pm 4.90 \mathrm{~d}$ & $169.11 \pm 3.71 \mathrm{c}$ & $1.45 \pm 0.03 a$ \\
\hline Okutukutu & $0.8 \mathrm{I} \pm 0.60 \mathrm{~b}$ & $0.50 \pm 0.7 \mathrm{Ib}$ & $250.18 \pm 9.30 b$ & $161.10 \pm 4.17 d$ & $2.79 \pm 0.4 \mathrm{Id}$ \\
\hline Etegwe & $0.68 \pm 0.3 \mathrm{lb}$ & $0.58 \pm 1.2 \mathrm{I} a b$ & $|75.4| \pm 6.12 \mathrm{a}$ & $90.3 \mathrm{I} \pm 0.1 \mathrm{Ia}$ & $3.94 \pm 0.53 b$ \\
\hline Akenpai & I. $27 \pm \mathrm{I} .43 \mathrm{~b}$ & $0.77 \pm 0.62 \mathrm{ab}$ & $|97.2| \pm 0.27 c$ & $81.15 \pm 9.90 d$ & $2.5 I \pm 0.4 I c$ \\
\hline Agudama & $0.65 \pm 0.1 \mathrm{lb}$ & $0.46 \pm 0.33 a$ & $217.09 \pm 2.88 c$ & $97.67 \pm 2.70 b$ & $3.42 \pm 0.8 \mathrm{la}$ \\
\hline Control & $0.49 \pm 0.4 \mathrm{la}$ & $0.80 \pm 0.19 d$ & $\mid 34.14 \pm 5.1 \mathrm{Id}$ & $78.52 \pm 4.12 \mathrm{a}$ & $0.4 I \pm 0.02 \mathrm{ab}$ \\
\hline
\end{tabular}

Each value is expressed as mean \pm standard error $(n=3)$. Different letters in each column indicate significant differences at $P<0.05$ according to the Duncan Statistics.

\section{Conclusion}

The research investigated the physicochemical and mirobiological assessment of some creeklet associated with urban runoff. Unfortunately, results indicated significant level of microbial contamination due to anthropogenic activities. On the other hand, most physicochemical parameters indicated mild level of contamination, as they complied with regulatory limits. The significant level of microbes is an indication that the creeklet water is unfit for consumption and most domestic and aesthetic purpose. The leachability of toxic leachate of urban runoff is largely implicated in the pollution of surface water. As such, we therefore urge government and all stakeholders to formulate policies to check the anthropogenicity of urban runoff, due to the fragility of the study area as a wetland prone to flooding.

\section{Acknowledgements}

None.

\section{Conflict of interest}

The author declares that there is no conflict of interest.

\section{References}

1. Angaye TCN, Zige DV, Izah SC. Microbial load and heavy metals properties of leachates from solid wastes dumpsites in the Niger Delta, Nigeria. Journal of Environmental Treatment Techniques. 2015;3(3):175180 .
2. Izonfuo LWA, Bariweni AP. The Effect of Urban Runoff Water and Human Activities on Some Physico-Chemical Parameters of the Epie Creek in the Niger Delta. J Appl Sci Environ Mgt. 2001;5(1):47-55.

3. Agedah EC, Ineyougha ER, Izah SC, et al. Enumeration of total heterotrophic bacteria and some physico-chemical characteristics of surface water used for drinking sources in Wilberforce Island, Nigeria. Journal of Environmental Treatment Techniques. 2015;3(1):28-34.

4. InoueT, Ebise S. Runoff Characteristics of COD, BOD, C, N and P Loading from Rivers to enclosed Coastal Seas. Marine Pollution Bulletin. 1991;23:11-14

5. Inanc B, Kinaci C, Ozturk I, et al. Pollution Prevention and Restoration in the Golden Horn of Istanbul. Wat Sci Tech. 1998;37(8):129-136.

6. Martin JC, Hoggart C, Matissa A. Improvement Priorities for Sewage Treatment in Latvian Small and Medium Sized Towns. Wat Sci Tech. 1998;37(8):137-144

7. Nwidu LL, Oveh B, Okoriye T, et al. Assessment of the Water Quality and Prevalence of Water Borne Diseases in Amassoma, Niger Delta, Nigeria. African Journal of Biotechnology. 2008;7(17):2993-2997.

8. Ukpong EC, Okon BB. Comparative Analysis of Public and Private Borehole Water Supply Sources in Uruan Local Government Area of Akwa Ibom State. International Journal of Applied Science and Technology. 2013;3(1):76-91.

9. Sunday JJ, Spencer NCO, Kingsley O, et al. Physico-chemical and microbiological properties of water samples used for domestic purposes in Okada town, Edo state, Nigeria. International Journal of Current Microbiology Applied Science. 2014;3(6):886-894. 
10. APHA. Standard Methods for the Examination of water and waste water 20th edition. American Public Health Association (APHA). Washington; 1998.

11. Benson HJ. Microbiological Applications: Laboratory Manual in General Microbiology/complete version, 5th edition. McGaraw-Hill: New York; 2002.

12. Itah AY, Ben AE. Incidence of Enteric Bacteria and Staphylococcus aureus in day care centres in Akwa Ibom State, Nigeria. Southeast Asian J Trop Med Public Health. 2004;35(1):202-209.

13. Aghoghovwia OA, Ohimain EI. Physicochemical characteristics of lower Kolo creek, Otuogidi, Bayelsa state. Nigerian Journal of Agriculture, Food and Environment. 2014;10(1):23-26.

14. Seiyaboh EI, Ogamba EN, Utibe DI. Impact of Dredging on the Water Quality of Igbedi Creek, Upper Nun River, Niger Delta, Nigeria. IOSR Journal of Environmental Science, Toxicology and Food Technology. 2013a;7(5):51-56.

15. Abowei JFN. Salinity, dissolved oxygen, $\mathrm{pH}$ and surface water temperature conditions in Nkoro River, Niger Delta, Nigeria. Advance Journal of Food Science and Technology. 2010;2(1):36-40.
16. Ohimain EI, Inyang IR, Angaye TC, et al. Prevalence of Catfish Diseases in Bayelsa State: A Case Study of Kolokuma/ Opokuma Local Government Area, Kolga, Nigeria. The Journal of Veterinary Science. 2013a;114:259-266.

17. Ezekiel EN, Hart AI, Abowei JFN. The Physical and Chemical Condition of Sombreiro River, Niger Delta, Nigeria. Research Journal of Environmental and Earth Sciences. 2011;3(4):327-340.

18. Seiyaboh EI, Inyang IR, Gijo AH. Environmental Impact of Tombia Bridge Construction across Nun River in Central Niger Delta, Nigeria. The International Journal of Engineering and Science. 2013b;2(11):3241

19. Cheesbrough. District Laboratory Practice In Tropical Countries. Part 2, second edition Cambridge University press, The Edinburgh Building, Cambridge: United Kingdom; 2006;38:62-69.

20. Puyate YT, Rim Rukeh A. Some physico-chemical and biological characteristics of soil and water samples of part of the Niger Delta area, Nigeria. J Appl Sci Environ Manage. 2008;12(2):135-141.

21. Ohimain EI, Angaye TNC, Ofongo RTS. The Challenge of Microbial and Parasitic Infections in Catfish Farming. The Journal of Veterinary Science. 2013b;114:301-309. 